\title{
Development of Iridium Based Fluorimetric Method for Determination of Cysteine
}

\section{Sistein Tayini için İridyum Tabanlı Fluorimetrik Metot Geliştirilmesi}

\author{
Özlem Biçen Ünlüer \\ Department of Chemistry, Faculty of Sciences, Eskişehir Teknik University, Yunus Emre Campus, Eskişehir, Turkey.
}

A B STRACT

Cysteine (Cys) and homocysteine ( $\mathrm{Hcy}$ ) amino acids that are containing thiol groups play many important roles in bi-

ological systems. The plasma level of Hcy is known to be an indicator of some disorders such as cardiovascular and Alzheimer's disease. Cys deficiency in plasma is associated with liver damage, muscle and fat loss, skin lesions, slowed growth, etc. In this study, iridium-based complexes were chosen for developing a fluorescent-based method for the determination of Cys levels due to their high photoluminescence efficiency. For this aim, the iridium (III) complex was synthesized then, this complex interacted with Cys solutions. It was found that, as the concentration of Cys interacting with the iridium complex, the fluorescence intensity increased. Based on these data, it was thought that the synthesized iridium complex could be used in the fluorimetric determination of Cys level in serum samples.

\section{Key Words}

Cysteine determination, iridium complex, fluorimetric determination.

\section{öz}

\footnotetext{
Tiyol grupları içeren aminoasitler olarak Sistein (Cys) ve homosistein (Hcy) biyolojik sistemlerde birçok önemli rol oynamaktadır. HCy'nin plazma seviyesinin, kardiyovasküler ve Alzheimer gibi bazı hastalıkların bir göstergesi olduğu bilinmektedir. Plazmadaki Cys eksikliği karaciğer hasarı, kas ve yağ kaybı, cilt lezyonları, yavaş büyüme vb. Gibi durumlarla ilişkilidir. Bu çalışmada, Cys seviyelerinin belirlenmesi için floresan tabanlı bir metot geliştirilmek üzere yüksek fotolüminesans etkinlik gösteren iridium (III) kompleksleri seçilmiştir. Daha sonra sentezlenen kompleks, Cys çözeltileriyle etkileştirilmiştir. İridyum kompleksiyle etkileşen Cys derişimi arttıkça çözeltinin floresans şiddetinin de arttığı bulunmuştur. Buradan yola çıkarak, sentezlenen iridyum kompleksinin, serum örneklerinde Cys seviyesinin florimetrik tayininde kullanılabileceği düşünülmektedir.
}

\section{Anahtar Kelimeler}

Sistein tayini, iridium kompleksi, florimetrik tayin.

Article History: Received: Sep 24, 2020; Revised: Feb 15, 2021; Accepted: Feb 16, 2021; Available Online: Jun $10,2021$.

DOI: https://doi.org/10.15671/hjbc.798021

Correspondence to: Ö. Biçen Ünlüer, Department of Chemistry, Faculty of Sciences, Eskişehir Teknik University, Eskişehir, Turkey.

E-Mail: obicen@eskisehir.edu.tr 


\section{INTRODUCTION}

- luorescent detection systems and bioimaging has - become an active research field in recent years. Fluorescent probes play a major role in the detection system because of their rapid and easy to observe facilities. For this reason, fluorescent proteins, luminescent nanoparticles [1,2], quantum dots [3-6], organic dyes [7] and fluorescent or phosphorescent heavy-metal complexes [8,9] are widely used in detection and bioimaging systems.

Sulfur-containing amino acids affect the cardiovascular system through abnormalities of hemostasis, coagulation, and blood vessel architecture mechanisms $[10,11]$. For instance, the level of homocysteine (HCys) which is a type of sulfur-containing amino acid has a crucial role to determine the vitamin deficiency, heart disease or a rare inherited disorder. In metabolism, vitamin B12, vitamin B6, and folic acid break down HCys and convert it into the needings of the body. Sulfurcontaining another aminoacid Cysteine (Cys) has an important role in metabolism as a key extracellular reducing agent and being a limiting precursor for glutathione synthesis $[11,12]$. Cys level is positively related to some disease such as cholesterol, diastolic blood pressure etc. [13] Cys deficiency is associated with slowed growth, hair depigmentation, oedema, lethargy, liver damage, muscle and fat loss, skin lesions, and weakness. Therefore, the determination of HCys and Cys in biological systems has great importance.

Several chromatographic and spectrophotometric methods have been developed for the determination of Cys and HCys in biological samples and drugs such as thin-layer chromatography, gas chromatography, highperformance liquid chromatography, electroanalytical techniques, circular dichroism, spectrofluorimetry, capillary electrophoresis [14-22]. However, the sample preparation has a long time and based on the analysis process, the determination time could be prolonged and some techniques use toxic reagents.

In this study, a new turn-on fluorescent-based method for the determination of Cys levels due to their high photoluminescence efficiency has been developed. In this technique, a heavy metal complex has been designed which could show fluorescence activity when interacting with Cys, and which lost its fluorescent feature when Cys was separated from the complex. Heavy-me- tal complexes such as $\operatorname{Re}(\mathrm{I})-, \operatorname{Ru}(\mathrm{II})-, \mathrm{Os}(\mathrm{II}), \operatorname{Ir}(\mathrm{III})$ - and $\mathrm{Rh}$ (III) complexes with $\mathrm{d}^{6}$ electronic structures, Pt(II) complexes with $\mathrm{d}^{8}$ electronic structures, and $\mathrm{Au}(\mathrm{I})$ - and $\mathrm{Cu}(\mathrm{I})$ complexes with $\mathrm{d}^{10}$ electronic structures, have great importance in bioimaging and bio labelling studies at room temperature [23-26]. Heavy metal complexes have some advantageous parts in terms of photophysical properties. Some of those advantages are: They have high luminescence efficiency and excitation and emission wavelength range could be realized easily. Besides these, they have relatively long lifetimes than organic luminophores. Iridium has been chosen as the heavy metal in this study as the complex due to its photoluminescence efficiency and excellent color tunability. Compared with other heavy metals and fluorescent dyes, iridium (III) based complexes show relatively long lifetime and high photostability. So, iridium complexes could be used as luminescent probes [27-29] besides the usage of bio labelling and chemosensing systems. In bioimaging techniques, fluorescence imaging is a powerful technique because it provides a subcellular level information [30].

In bioimaging applications, water-solubility of the fluorescent heavy-metal complexes in bioimaging or bio labelling studies is very important because the interaction media would be water or buffer solution. When the water-solubility of the fluorescent probe is very low, sometimes the addition of the organic solvents (such as DMSO) in aqueous media is required. This process is harmful and makes the toxic effect on the biomolecules (ie. destroying the cell membrane) during the imaging or labelling process so limits the efficiency of the fluorescent probe. Therefore, the developed fluorescent probe based on heavy-metals should be water-soluble probes to eliminate the application limits during the bioimaging process.

In this work, a complete water-soluble cationic iridium (III) complex, $\left[\mathrm{Ir}(\mathrm{ppyCHO})_{2} \mathrm{Cl}_{2}\right] \mathrm{Cl}$ (trans-dichlorobis[4(pyridine-2-yl) benzaldehyde iridium (III) chloride), has been synthesized for the detection of cysteine. When this complex interacted with Cys, $\left[\operatorname{Ir}(\text { ppyCOCys })_{2} \mathrm{Cl}_{2}\right] \mathrm{Cl}$ complex has been formed and fluorescence emission has occurred. So it could be adequate as a fluorescent probe for Cys detection. 
<smiles>Brc1ccccn1</smiles>

2-bromopyridine

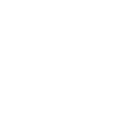

$\mathrm{HO}$

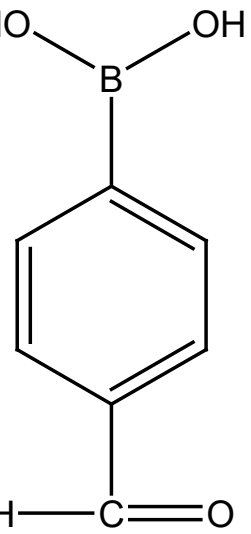

4-formylphenylboronic acid

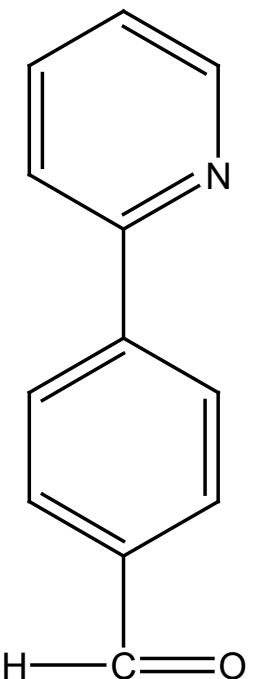

4-(pyridin-2-yl)benzaldehyde

Figure 1. Schematic reaction of the ligand, 4-(pyridine-2yl) benzaldehyde synthesis.

\section{MATERIAL and METHODS}

\subsection{Materials}

In this study, L-cysteine (Sigma-Aldrich), 4-(2-Hydroxyethyl) piperazine-1- ethane sulfonic acid (HEPES, $\geq$ 99.5\%, Sigma- Aldrich), dimethyl sulfoxide (DMSO, from local sources), 2- Bromo pyridine (Sigma-Aldrich), 4-formyl phenylboronic acid ( $\geq 95.0 \%$, Sigma-Aldrich), potassium carbonate (from local sources), tetrakis(triphenylphosphine) palladium $\left(\mathrm{Pd}\left(\mathrm{PH}_{3}\right)_{4}\right.$, Sigma-Aldrich), dioxane (from local sources), dichloromethane(from local sources), magnesium sulfa-

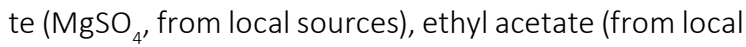
sources), hexane (from local sources), 2-ethoxyethanol (analytical standard, sigma-Aldrich) and ether (from local sources) were used in synthesis.

In the characterization and experimental process, ${ }^{1} \mathrm{H}-\mathrm{NMR}$ and ${ }^{13} \mathrm{C}$-NMR spectra were recorded on a Bruker Advance 500 DPX spectrometer in chloroform-d $\left(\mathrm{CDCl}_{3}\right)$ with tetramethylsilane (TMS) as the internal standard, UV-visible spectra, fluorescence spectra and Fourier transform infrared (FTIR) spectra were recorded using, Shimadzu UV - 2101 PC, Varian Cary Eclipse and Perkin Elmer, respectively.

\subsection{Methods}

Detection of Cys levels was achieved using the fluorescence emission after interaction Ir complex with Cys. [ $\mathrm{Ir}(\mathrm{ppyCHO})_{2} \mathrm{Cl}_{2}$ ] $\mathrm{Cl}$ complex was used as a watersoluble fluorescence probe and it was synthesized into two steps. First, the 4-(pyridine-2yl) benzaldehyde complex has been synthesized as the ligand. Secondly, it was reacted with iridium (III) chloride to obtain [ Ir (ppyCHO $\left.)_{2} \mathrm{Cl}_{2}\right] \mathrm{Cl}$ complex as a selective fluorescence Ir complex for Cys via electron transfer occurred interacted with Cys. When $\left[\mathrm{Ir}(\mathrm{ppyCHO})_{2} \mathrm{Cl}_{2}\right] \mathrm{Cl}$ complex interacted with Cys, $\left(\left[\operatorname{Ir}(\text { ppyCHO})_{2} \mathrm{Cl}_{2}\right] \mathrm{Cl} / \mathrm{Cys}\right.$ fluorescent complex was formed and fluorescence emission occurred via electron transfer from the thiazolidine group to the excited metal-to-ligand charge transfer.

\subsubsection{Ligand Synthesis}

Prior to the synthesis of 4-(pyridine-2yl) benzaldehyde ligand, 2-Bromoprydine (1 eq, $0.4 \mathrm{~mL}$ ), 4-formylphenyIboronic acid (1.5 eq, $0.930 \mathrm{~g}$ ), $\mathrm{K}_{2} \mathrm{CO}_{3}$ (3 eq, $1.7 \mathrm{~g}$ ), Pd $\left(\mathrm{PH}_{3}\right)_{4}$ (0.150 mg) were added to $100 \mathrm{~mL}$ volumetric flask and reaction were refluxed at $97^{\circ} \mathrm{C}$ in dioxane $/ \mathrm{H}_{2} \mathrm{O}$ (4:1) for $12 \mathrm{~h}$. The reaction was followed with thin-layer chromatography (TLC) and the reaction finished after 


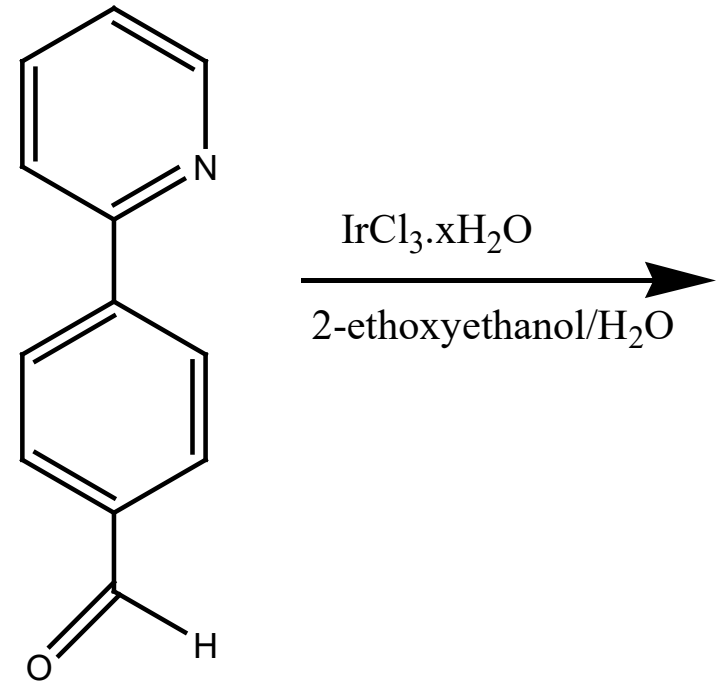

Figure 2. Synthesis procedure of $\left[\mathrm{Ir}(\mathrm{ppyCHO})_{2} \mathrm{Cl}_{2}\right] \mathrm{Cl}$ complex.

2 days. The reaction solution was filtrated, the solvent was evaporated and the precipitate was put into dichloromethane. The mixture was extracted with water three times. The organic phase was dried with $\mathrm{MgSO}_{4}$. The column was set up for the purification (mobile phase: 1:9 ethyl acetate: hexane). After this process, 0.171 $\mathrm{g}$ ligand was obtained.

\subsubsection{Iridium Complex Synthesis and Characterization}

In the synthesis of $\left[\mathrm{Ir}(\mathrm{ppyCHO})_{2} \mathrm{Cl}_{2}\right] \mathrm{Cl}$ complex, $\mathrm{IrCl}_{3} \cdot \mathrm{H}_{2} \mathrm{O}$ (0.138g / 1 eq) was added to $6.171 \mathrm{~g}$ (2.16 eq) 4-(pyridine$2 \mathrm{yl}$ ) benzaldehyde ligand and was mixed in $16 \mathrm{~mL}$ 2-ethoxyethanol/ $\mathrm{H}_{2} \mathrm{O}$ at $120^{\circ} \mathrm{C}$ during 1 night. At the end of the reaction, the mixture was cooled at room temperature. Ether was added to the reaction media. Orange precipitate was obtained and these precipitates were filtrated. At the end of this process, $\left[\operatorname{Ir}(\text { ppyCHO })_{2} \mathrm{Cl}_{2}\right] \mathrm{Cl}$ was synthesized and characterized via FTIR, ${ }^{1} \mathrm{H}-\mathrm{NMR}$, and ${ }^{13} \mathrm{C}-\mathrm{NMR}$ analysis.

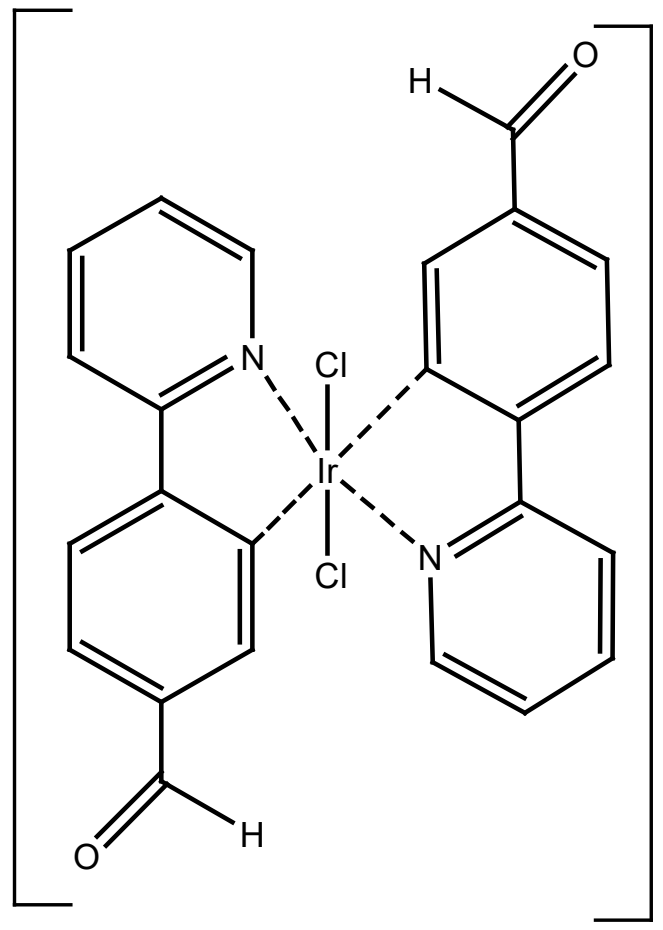

\subsubsection{The Detection of Cysteine by Using the Developed Fluorescent Probe}

Cys solutions in different concentrations $(0,1 \mathrm{M}$ to $0,5 \mathrm{M})$ in HEPES buffer has been prepared as standard Cys solutions. The calibration curve was plotted according to UV absorbance at $230 \mathrm{~nm}$ of standard Cys solutions. For determination of the efficiency of the synthesized $\left[\mathrm{Ir}(\mathrm{ppyCHO})_{2} \mathrm{Cl}_{2}\right] \mathrm{Cl}$ complex as a fluorescent probe, Cys solutions interacted with $200 \mu \mathrm{L}$ of $100 \mathrm{ppm}$ $\left[\mathrm{Ir}(\mathrm{ppyCHO})_{2} \mathrm{Cl}_{2}\right] \mathrm{Cl}$ complex and fluorescence intensity was recorded.

\section{RESULTS and DISCUSSION}

\subsection{Characterization of Synthesized Iridium Complex}

In the characterization process, the functional groups in the structure of synthesized $\left[\mathrm{Ir}(\mathrm{ppyCHO})_{2} \mathrm{Cl}_{2}\right] \mathrm{Cl}$ complex has been determined by FTIR analysis. Figure 3 showed the FTIR spectrum and according to the data, the aldehyde group $(C=O)$ peaks were obtained approxima- 


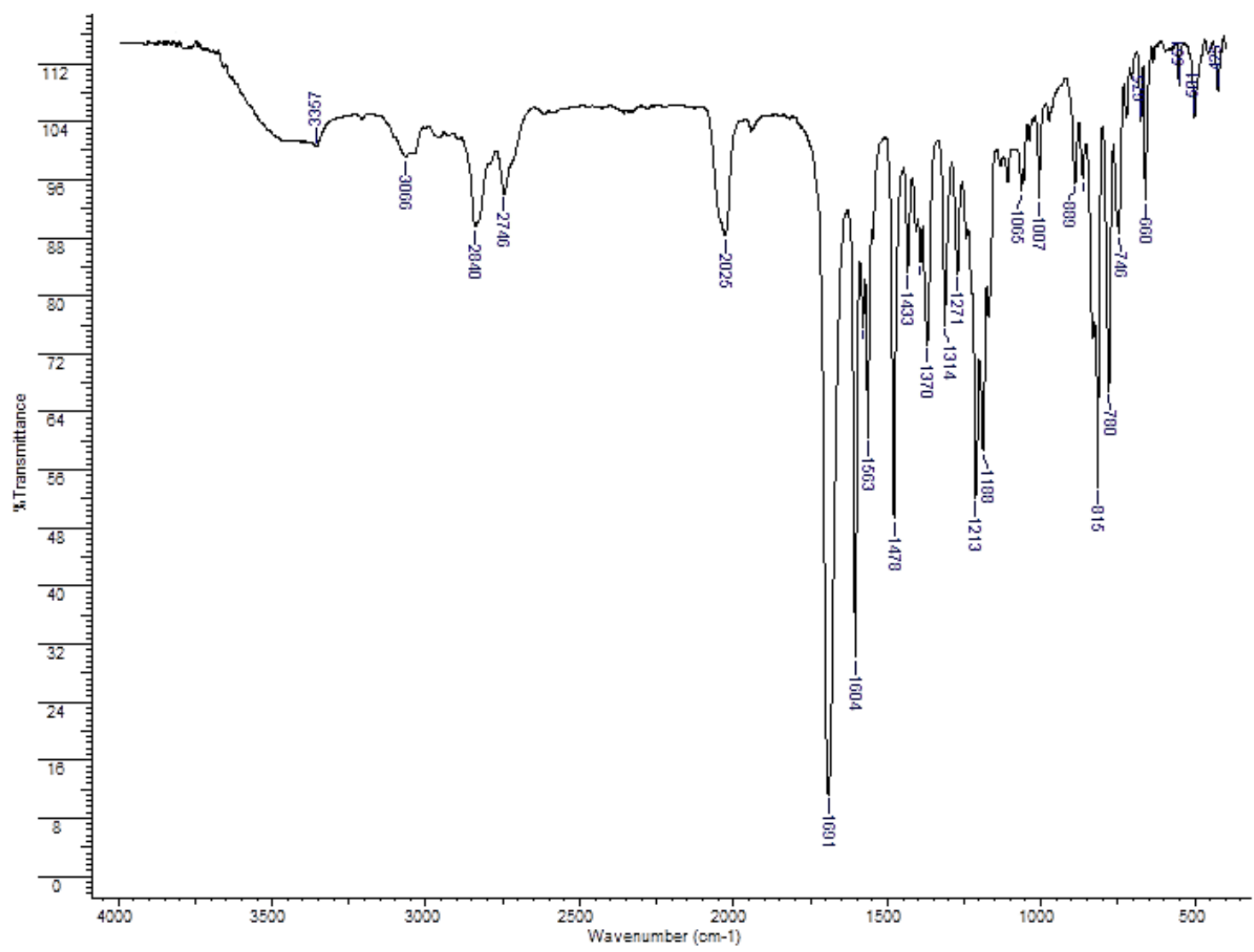

Figure 4. FTIR spectra of $\left[\mathrm{Ir}(\text { ppyCHO })_{2} \mathrm{Cl}_{2}\right] \mathrm{Cl}$ complex.

tely at $1725 \mathrm{~cm}^{-1}$. Also, peaks at approximately 2800 $\mathrm{cm}^{-1}$ are related to $\mathrm{C}-\mathrm{H}$ aldehyde stretches. Aromatic group peaks were shown at approximately $3000 \mathrm{~cm}^{-1}$. The peaks around $1600 \mathrm{~cm}^{-1}$ and approximately 1450 $\mathrm{cm}^{-1}$ indicated the $\mathrm{C}=\mathrm{C}$ groups in the aromatic group. The synthesized iridium complex had halogen group (Cl) in its structure and peaks at $540 \mathrm{~cm}^{-1}$ and $780 \mathrm{~cm}^{-1}$ indicated the halogen stretch. Peaks in approximately 1550 $\mathrm{cm}^{-1}$ and $1650 \mathrm{~cm}^{-1}$ were related to the $\mathrm{C}=\mathrm{N}$ bonds.

Another characterization about the structure of the synthesized iridium (III) complex, [Ir(ppyCHO)2Cl2] $\mathrm{Cl}$, was NMR analysis. Figures $5 \mathrm{a}$ and $5 \mathrm{~b}$ showed the ${ }^{1} \mathrm{H}-\mathrm{NMR}$ and the ${ }^{13} \mathrm{C}-\mathrm{NMR}$, respectively. ${ }^{1} \mathrm{H}-\mathrm{NMR}$ (400 $\mathrm{MHz}, \mathrm{CDCl}_{3}$ ) data for the complex was $\delta=10.05$ (s, 1H), 9.48 (s, 1H), 7.99 (d, 3H), 7.84 (d, 2H), 7.73 (d, $1 \mathrm{H})$. According to the data in the ${ }^{1} \mathrm{H}-\mathrm{NMR}$ spectra of [Ir $\left.(\text { ppyCHO })_{2} \mathrm{Cl}_{2}\right] \mathrm{Cl}$ complex, aldehyde proton substituted for the phenyl pyridine ligand appeared to a singlet at $10.05 \mathrm{ppm}$. The two doublet peaks observed at 7.99 ppm and $7.84 \mathrm{ppm}$ are related to phenyl and pyridine ring protons. The proton signal $(\mathrm{Hb})$ adjacent to the pyridine nitrogen is observed at $9.48 \mathrm{ppm}$ due to its resonance in the lower area.

${ }^{13} \mathrm{C}$ NMR (100 MHz, $\mathrm{CDCl}_{3}$, TMS) data for the complex was $\delta=191.58,155.30,150.17,142.85,137.87,131.78$, $130.18,126.99,123.77,121.31 \mathrm{ppm}$. According to the data in the ${ }^{13} \mathrm{C}-\mathrm{NMR}$ spectrum, aldehyde carbon signal was observed at $191.58 \mathrm{ppm}$. The signals of quaternary carbons in phenyl pyridine observed as low-intensity signals at 155.30, 142.85 ppm and 131.78 ppm. The C atom in the phenyl ring was observed as a quaternary peak at $123.77 \mathrm{ppm}$ after bonding to the metal. All the proton and carbon signals exactly correspond to the complex structure. 
(A)

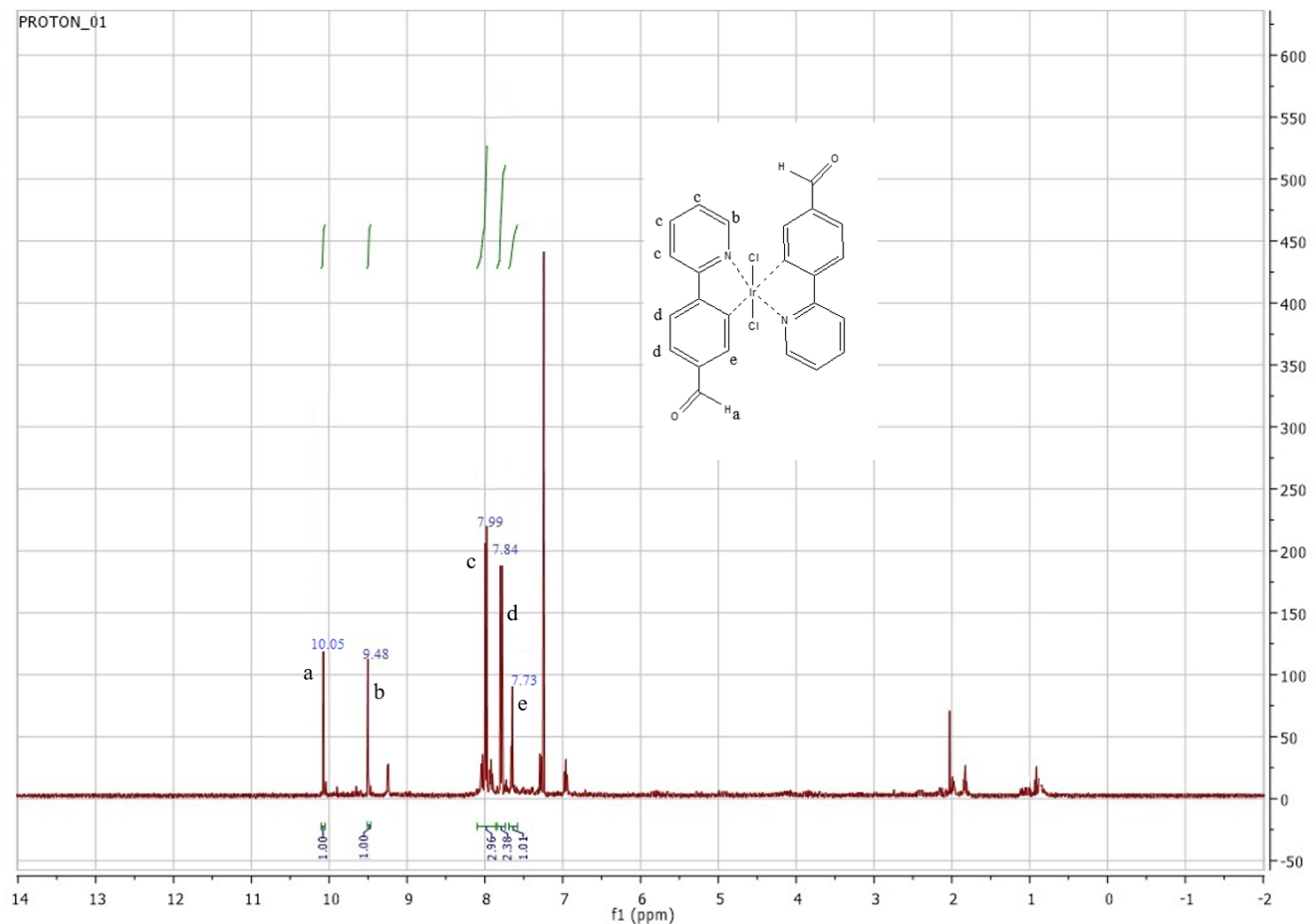

(B)

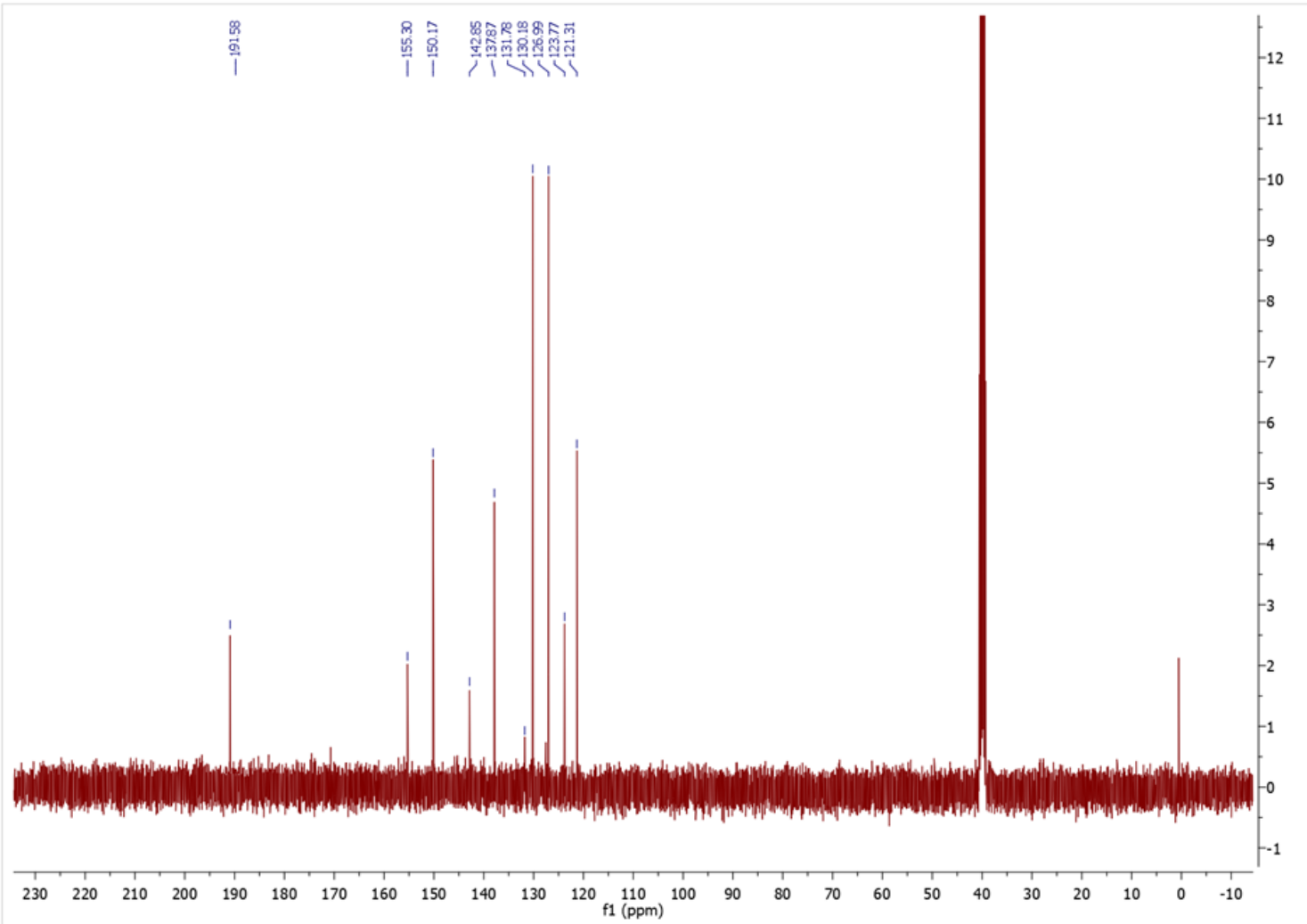

Figure 5. A) ${ }^{1} \mathrm{H}-\mathrm{NMR}(400 \mathrm{MHz}, \mathrm{CDCl})$, B) ${ }^{13} \mathrm{C}-\mathrm{NMR}\left(100 \mathrm{MHz}, \mathrm{CDCl}{ }_{3}, \mathrm{TMS}\right)$ data for synthesized $\left[\mathrm{Ir}(\mathrm{ppyCHO})_{2} \mathrm{Cl}_{2}\right] \mathrm{Cl}$ complex. 
When all characterization results were evaluated, it was observed that the $\left[\mathrm{Ir}(\text { ppyCHO})_{2} \mathrm{Cl}_{2}\right] \mathrm{Cl}$ complex synthesis has been achieved successfully.

\subsection{The Detection of Cysteine by Using the Developed Fluorescent Probe}

Before the analysis as a fluorescent probe with synthesized $\left[\mathrm{Ir}(\mathrm{ppyCHO})_{2} \mathrm{Cl}_{2}\right] \mathrm{Cl}$ complex, cysteine solutions in HEPES buffer in different concentrations (0.1 $\mathrm{M}$ to $0.5 \mathrm{M})$ were prepared and UV absorbance was recorded. It has been observed that UV absorbance values increased with increasing concentrations of Cys at 230 $\mathrm{nm}$. The study of Zhang et al. [31] showed that cysteine had characteristic UV band at $230 \mathrm{~nm}$ in coordination and ligand replacement reactions. So, the band at 230 $\mathrm{nm}$ indicated the coordination reaction of cysteine in Figure 6.

After this analysis, each Cys solutions interacted with 100 ppm of synthesized $\left[\mathrm{Ir}(\mathrm{ppyCHO})_{2} \mathrm{Cl}_{2}\right] \mathrm{Cl}$ complex. After this interaction, the fluorescence spectrum was obtained for each [ $\mathrm{Ir}$ (ppyCOCys) $\left.\mathrm{Cl}_{2}\right] \mathrm{Cl}$ solution by excitation at $320 \mathrm{~nm}$. Fluorescent emission at $610 \mathrm{~nm}$ was obtained for each solution due to electron transfer from the thiazolidine group to the excited metal-to-ligand charge transfer. So, $\left[\mathrm{Ir}(\mathrm{ppyCHO})_{2} \mathrm{Cl}_{2}\right] \mathrm{Cl}$ complex performed a fluorescent probe in $\mathrm{Cys}$ detection. The reaction between $\mathrm{Cys}$ and $\left[\mathrm{Ir}(\mathrm{ppyCHO})_{2} \mathrm{Cl}_{2}\right] \mathrm{Cl}$ complex and fluorescence spectra of $\left[\mathrm{Ir}(\text { ppyCOCys })_{2} \mathrm{Cl}_{2}\right] \mathrm{Cl}$ solution was shown in Figure 7 and Figure 8, respectively. It was seen that the fluorescent intensity of obtained $\left[\operatorname{Ir}\left(\right.\right.$ ppyCOCys) $\left.{ }_{2} \mathrm{Cl}_{2}\right] \mathrm{Cl}$ increased by increasing the concentration of Cys that is interacted with $\left[\mathrm{Ir}(\mathrm{ppyCHO})_{2} \mathrm{Cl}_{2}\right] \mathrm{Cl}$ complex.

Overall, transition metal complexes provide the development of bioimaging and detection method via fluorescence due to their high luminescence efficiency and excitation and emission wavelength range. Among the transition metal complexes, iridium complexes are attractive materials because they exhibit high photostability and long life-time.

As a result, the iridium complex containing aldehyde group, $\left[\mathrm{Ir}(\mathrm{ppy} \mathrm{CHO})_{2} \mathrm{Cl}_{2}\right] \mathrm{Cl}$, was designed as Cys selective detection tool for fluorescence detection. Fluorescence feature of the designed system was investigated using Cys solutions (the concentration range: $0.1 \mathrm{M}-0.5 \mathrm{M}$ )

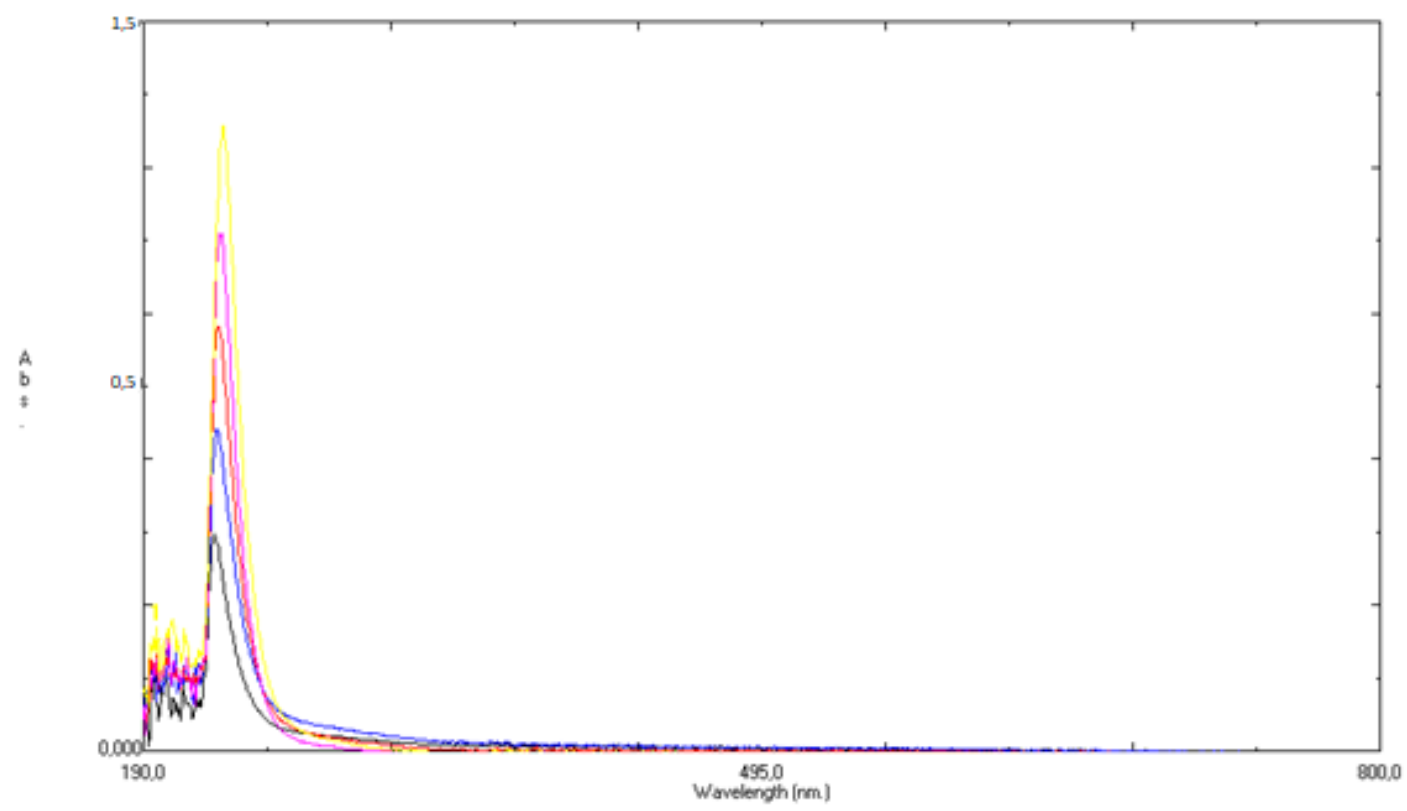

Figure 6. UV spectra of Cysteine ( $0.1 \mathrm{M}$ to $0.5 \mathrm{M}$, at $230 \mathrm{~nm}$, in HEPES buffer). 
interacted with $\left[\mathrm{Ir}(\mathrm{ppyCHO})_{2} \mathrm{Cl}_{2}\right] \mathrm{Cl}$ complex at $320 \mathrm{~nm}$ as the excitation wavelength. This detection strategy based on the selective reaction of the aldehyde of the ligand 4-(2-pyridyl) benzaldehyde with an aminothiol group to form thiazolidine. This selective binding affected the conjugation between aldehyde and the phenyl moiety. So, when Cys bonded selectively to the synthesized iridium complex, a fluorescent emission has occurred at $610 \mathrm{~nm}$ and the changes in fluorescent could be visible by the naked eye. There are some studies in the literature on Cys determination using iridium complexes. Based on the properties of iridium-Cys based compounds formed at the end of the interaction of iridium complexes and Cys, a number of chemiluminescencebased, phosphorescence-based applications are seen $[32,33]$. The common problem of designing probes with transition metals was solubility in water that limited the probe designing. In this study, the proposed method proposed an easy-to-apply method using water-soluble probes to overcome application limits in Cys determination. According to the data, this developed fluorescence probe could be used in Cys determination in serum samples as a detection tool.

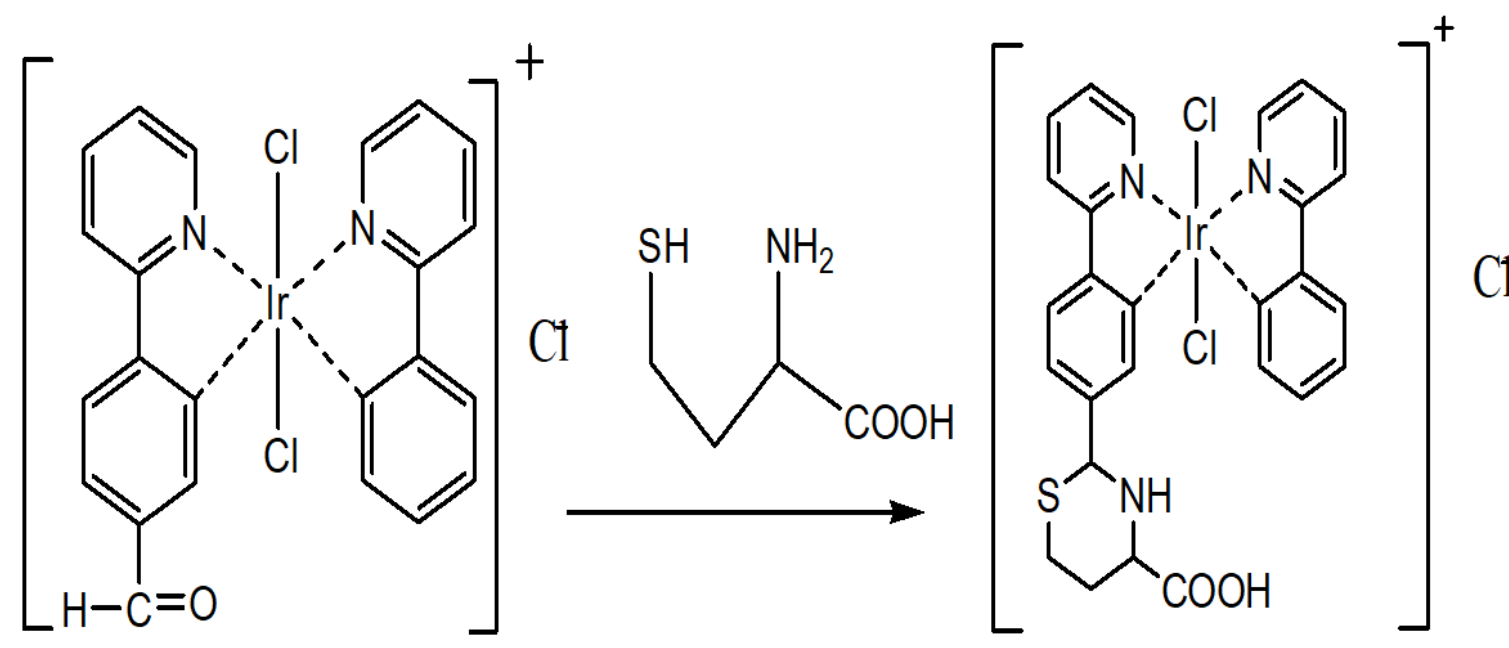

Figure 7. Reaction between $\mathrm{Cys}$ and $\left[\mathrm{Ir}(\mathrm{ppyCHO})_{2} \mathrm{Cl}_{2}\right] \mathrm{Cl}$ complex and formation of $\left[\mathrm{Ir}(\text { ppyCOCys })_{2} \mathrm{Cl}_{2}\right] \mathrm{Cl}$ complex. 


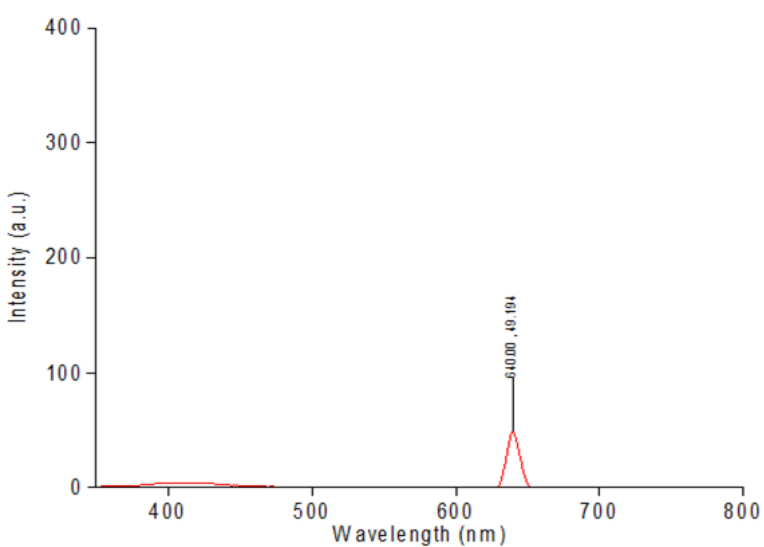

(a)

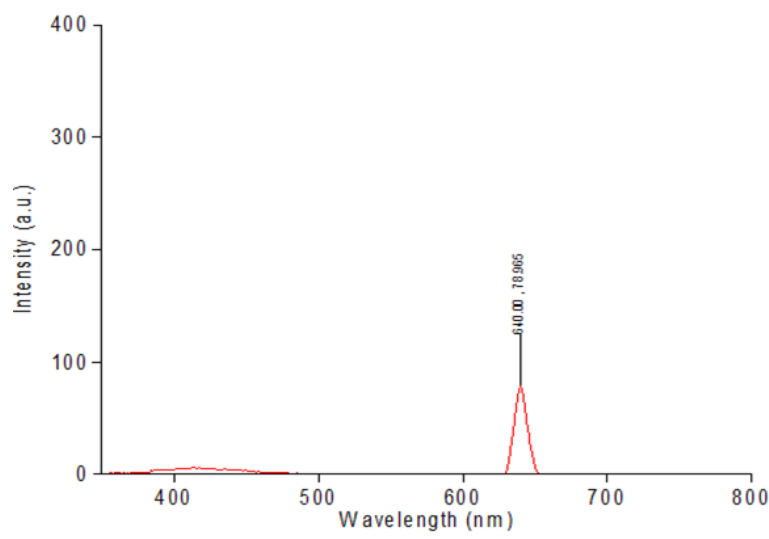

(c)

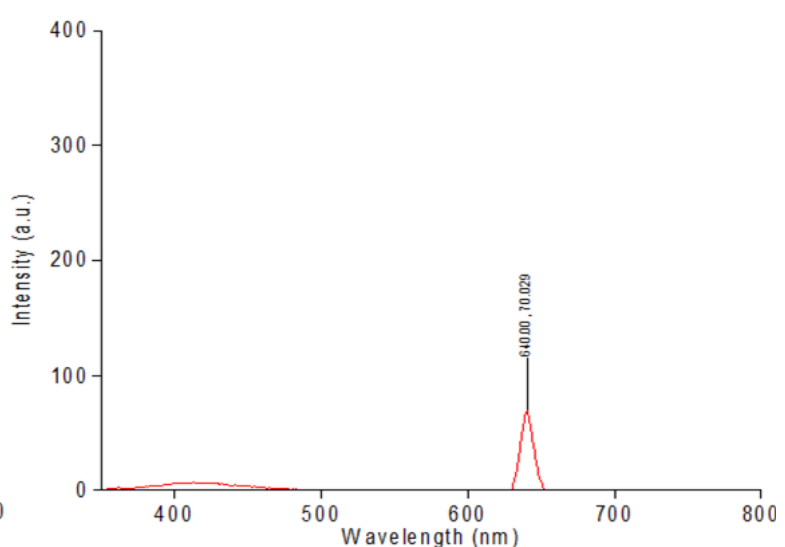

(b)

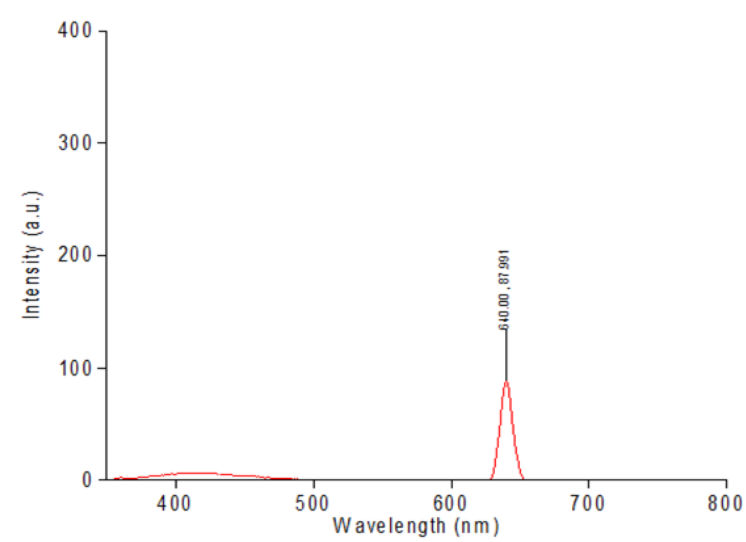

(d)

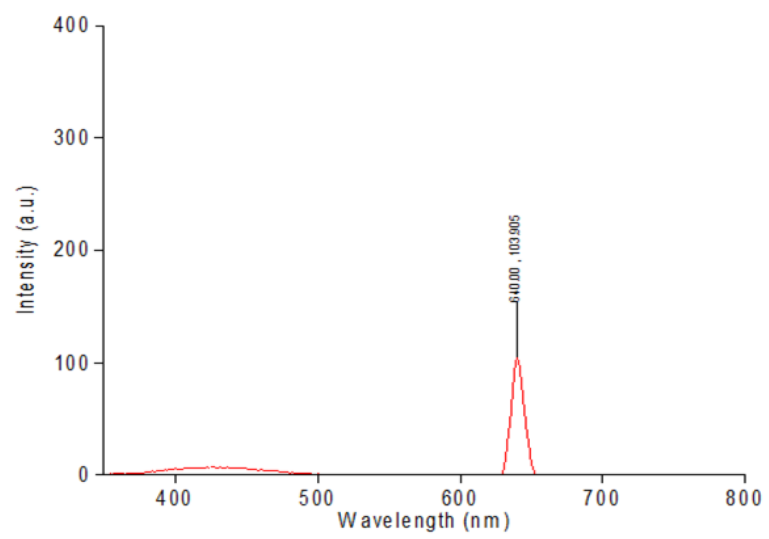

(e)

Figure 8. Fluorescence spectrum of the $\left[\mathrm{Ir}\left(\right.\right.$ ppyCOCys) $\left.\mathrm{Cl}_{2}\right] \mathrm{Cl}$ solution a) $0.1 \mathrm{M} \mathrm{Cys}$ b) $0.2 \mathrm{M}$ Cys c) $0.3 \mathrm{M} \mathrm{Cys}$ d) $0.4 \mathrm{M}$ Cys e) $0.5 \mathrm{M}$ Cys interacted with $100 \mathrm{ppm}\left[\mathrm{Ir}(\mathrm{ppyCHO})_{2} \mathrm{Cl}_{2}\right] \mathrm{Cl}$ complex. (Excitation: $320 \mathrm{~nm}$, emission: $610 \mathrm{~nm}$ ). 


\section{References}

1. Y. Sun, M. X. Yu, S. Liang, Y. J. Zhang, C. G. Li, T. T. Mou, W. J. Yang, X. Z. Zhang, B. Li and F. Y. Li, Fluorine-18 labeled rareearth nanoparticles for positron emission tomography (PET) imaging of sentinel lymoh node, Biomaterials, 32 (2011) 2999-3007.

2. T. Y. Cao, Y. Yang, Y. Gao, J. Zhou, Z. Li, F. Y. Li, High-quality water soluble and surface-functionalized upconversion nanocrystals as luminescent probes for bioimaging, Biomaterials, 32 (2011) 2959-2968.

3. M.Jr. Bruchez, M. Moronne, P. Gin, S. Weiss, A.P. Alivisatos, Semiconductor nanocrystals as fluorescent biological labels, Science, 281 (1998) 2013-2016.

4. W.C.W. Chan, S. Nie,Quantum dot Bioconjugates for Ultrasensitive Nonisotopic Detection, Science, 281 (1998) 2016-2018.

5. B. Dubertret, P. Skourides, D.J. Norris, V. Noireaux, A.H. Brivanlou, A. Libchaber, In vivo imaging of quantum dots encapsulated in phospholipid micelles, Science, 298 (2002) 1759-1762.

6. I.L. Medintz, H.T. Uyeda, E.R. Goldman, H. Mattoussi, Quantum dot bioconjugates for imaging, labelling and sensing, Nat. Mater., 4 (2005) 435-446.

7. J. Escobedo, O. Rusin, S. Lim, R.M.Strongin. NIR Dyes for bioimaging applications, Curr. Opin. Chem. Biol., 14 (2009) 64-70.

8. C.H. Huang, F.Y. Li, W. Huang, Intruduction to Organic LightEmitting Materials and Devices, Press of Fudan University, Shanghai, 2005.

9. Y. Ma, S. Liu, Y. Wu, C Yang, X. Liu, Q. Zhao, H. Wu, J. Liang, F. Li, W. Huang, Water-soluble phosphorescent iridium(iii) complexes as multicolor probes for imaging of homocysteine and cysteine in living cells, J. Mater. Chem. 21 (2011) 18974-18982.

10. W.S. Speidl, M. Nikfardjam, A. Niessner Mild hyperhomocysteinemia is associated with a decreased fibrinolytic activity in patients after ST-elevation myocardial infarction, Thromb Res., 119 (2007) 331-336.

11. S. Kostić, Ž Mićovic, L Andrejević,.The effects of L-cysteine and $\mathrm{N}$-acetyl-L-cysteine on homocysteine metabolism and haemostatic markers, and on cardiac and aortic histology in subchronically methionine-treated Wistar male rats, Mol. Cell Biochem., 451 (2019) 43-54.

12. P.M. Ueland, M.A. Mansoor, A.B. Guttormsen. Reduced, oxidized and protein-bound forms of homocysteine and other aminothiols in plasma comprise the redox thiols status-a possible element of the extracellular antioxidant defence system, J. Nutr., 126 (1996) 1281S-1281S4S.

13. M.A. Badgley, D.M. Kremer, H.C. Maurer, K.E. Delgıorno, H. Lee, V. Purohıt, I.R. Sagalovskıy, A. Ma, J. Kapılıan, C.E. M. Fırl, A.R. Decker, S.A. Sastra, C.F. Palermo, L.R. Andrade, P. Sajjakulnukıt, L. Zhang, Z.P. Tolstyka, T. Hırschhorn, C. Lamb, T. Lıu, W. Gu, E.S. Seeley, E. Stone, G. Georgıou, U. Manor, A. Iuga, G.M. Wahl, B.R. Stockwell, C.A. Lyssıotıs, K.P. Olıve, A drug that lowers intracellular cysteine levels inhibits growth of pancreatic tumors in mice by inducing a specific form of cell death, 368 (2020) 85-89.

14. M.E. Johll, D.G.Willimas, D.C.Johnson Activated pulsed amperometric detection of cysteine at platinum electrodes in acidic media Electroanalysis, 9 (1997), p. 1397.
15. A.Besada, N.B. Tadros, Y.A. Gawargious, Copper(II)neocuproine as color reagent for some biologically active thiols: spectrophotometric determination of cysteine, penicillamine, glutathione, and 6-mercaptopurine Microchim. Acta, 99 (1989) 143-146.

16. E. Tütem, R. Apak, Simultaneous spectrophotometric determination of cysteine in amino acid mixture using copper(II)-neocupoine reagent, Anal. Chim. Acta, 255 (1991) 121-125.

17. J. Chrastil, Spectrophotometric determination of cysteine and cystine in urine, Analyst, 15 (1990) 1383-1384.

18. T. Pérez-Ruiz, C. Martinez Lozano, V. Tomás, J. Carpena, Spectrofluorimetric flow injection method for the individual and successive determination of I-cysteine and I-cystine in pharmaceutical and urine samples, Analyst, 117 (1992) 1025-1028.

19. J. Russel, J.A. Mckeown, C. Hensman, W.E. Smith, J. Reglinski, HPLC determination of biologically active thiols using precolumn derivatization with 5, 5'-dithio-bis-2-nitro-benzoic acid, J. Pharm. Biomed. Anal., 15 (1999) 1757-1763.

20. W. Jin, Y. Wang, Determination of cysteine by capillary zone electrophoresis with end-column amperometric detection at a gold/mercury amalagm microelectrode without deoxygenation, J. Chromatogr. A., 769 (1997) 307-314.

21. R. Zhang, J. Yong, J. Yuan, Z.P. Xu, Recent advances in the development of responsive probes for selective detection of cysteine, Coordin. Chem. Rev., 408 (2020) 213182.

22. S.D. Naidu, A.T. Dinkova-Kostova. KEAP1, a cysteine-based sensor and a drug target for the prevention and treatment of chronic disease, Open Biol., 10200105 (2020).

23. Q. Zhao, S.J. Liu and W. Huang, Promising optoelectronic materials: polymers containing phosphorescent iridium(III) complexes, Macromol. Rapid Commun., 31 (2010) 794.

24. Z.Q. Chen, Z.Q. Bian, C.H. Huang, Functional Irlll complexes and their applications, Adv. Mater., 22 (2010) 1534.

25. W.Y. Wong, C.L. Ho, Heavy metal organometallic electrophosphors derived from multi-component chromophores, Coord. Chem. Rev., 253 (2009) 1709-1758.

26. Y. You, S.Y. Park, Phosphorescent iridium(iii) complexes: toward high phosphorescence quantum efficiency through ligand control, Dalton Trans., 8 (2009) 1267-1282.

27. M. Yu, X. Q. Zhao, L. Shi, F. Li, Z. Zhou, H. Yang, T. Yi, C. Huang, Cationic iridium (III) complexes for phosphorescence staining in the cytoplasm of living cells, Chem. Commun., 18 (2008) 2115-2117.

28. Q. Zhao, M. Yu, L. Shi, S. Liu, C. Li, M. Shi, Z. Zhou, C. Huang, F. Li, Cationic iridium (III) complexes with tunable emission color as phosphorescent dyes for live cell imaging, Organometallics, 29 (2010) 1085-1091.

29. K.Y. Zhang, S.P.Y. Li, N. Zhu; I.W. S Or, M.S.H Cheung, Y.W. Lam, K.K. W. Lo, Structure, photophysical and electrochemical properties, biomolecular interactions, and intracellular uptake of luminescent cyclometalated iridium(III) dipyridoquinoxaline complexes, Inorg. Chem., 49 (2010) 2530-2540.

30. M. Zhang, M. Yu, F. Li, M. Zhu, M. Li, Y. Gao, L. Li, Z. Liu, J. Zhang, D. Zhang, T. Yi, C. Huang, A highly selective fluorescence turn-on sensor for cysteine/homocysteine and its application in bioimaging, J. Am. Chem. Soc.,129 (2007) 10322-10323. 
31. L. Zhang, Y. Yuan, X. Wen, Y. Li, C. Cao, Q. Xiong, A coordination and ligand replacement based three-input colorimetric logic gate sensing platform for melamine, mercury ions, and cysteine, RSC Adv., 5 (2015) 59106-59113.

32. Y.P. Dong, M.J. Shi, B.H. Tong, Q.F. Zhang, Chemiluminescence of a cyclometallated iridium (III) complex and its application in the detection of cysteine, Luminescence, 27 (2014) 414418.
33. H. Chen, Q. Zhao, Y. Wu, F. Li, H. Yang, T. Yi, C. Huang, Selective phosphorescence chemosensor for homocysteine based on an iridium (III) complex, Inorg. Chem. 46 (2007) 11075-11081. 